VOX PATRUM 26 (2006) t. 49

Mirosław J. LESZKA

(Łódź, UŁ)

\title{
KONSTANTYNOPOL W LISTACH TEOFILAKTA, ARCYBISKUPA OCHRYDY
}

Teofilakt, jeden z najwybitniejszych bizantyńskich intelektualistów 2. poł XI i pierwszego ćwierćwiecza XII wieku, przyszedł na świat między rokiem 1050-1060 na wyspie Eubei ${ }^{1}$. Tu odebrał elementarne wykształcenie, później zaś wysłany został do Konstantynopola, z którym na dłuższy czas związał swoje życie. W stolicy Imperium Teofilakt kontynuował edukację, będąc być może uczniem m.in. samego Michała Psellosa ${ }^{2}$. Po zakończeniu nauki został diakonem w kościele Hagia Sofia i podjął działalność pedagogiczną w cieszącej się znaczną sławą szkole patriarchatu konstantynopolitańskiego ${ }^{3}$. Wiedza i umiejętności pedagogiczne zyskały mu spory autorytet, ponieważ powierzono mu ok. poł. lat 80-tych XI wieku edukację Konstantyna Dukasa, syna usuniętego z tronu w 1078 r. cesarza Michała VII i Marii z Alanii; Konstantyn miał być następcą Aleksego Komnena, ówczesnego władcy Imperium ${ }^{4}$. Dla swojego podopiecznego napisał mowę pod tytułem $O$ wykształceniu cesarz $a^{5}$. Konstantyn Dukas po narodzinach Jana, syna Aleksego Komnena, pozbawiony został szans na przejęcie władzy; następcą Aleksego miał zostać, co jest zrozumiałe,

${ }^{1}$ Miejscem jego urodzenia było Chalkis, stolica wyspy, lub Euripos. Na temat pochodzenia i edukacji Teofilakta por. P. Gautier, Introduction, w: Théophylacte d'Achrida, Discours - Traités Poésies. Introduction, texte, traduction et notes P. Gautier, t. 1, Thessalonique 1980, 11nn; (dalej: Gautier I); B. Panov, Teofilakt Ochridski kako izvor za srednovekovnata istorija na makedonskiot narod, Skopje 1985, 16-22; M. Mullet, Theophylact of Ochrid. Reading the Letters of a Byzantine Archbishop, Ashgate 1997, 43; D. Obolenski, Šest vizantijskich portretov, Moskva 1998, 427-428; Testimonia najdawniejszych dziejów Stowian, seria grecka z. 4: Pisarze z VIII-XII wieku, wyd. A. Brzóstkowska - W. Swoboda, Warszawa 1997, 181 (dalej: Testimonia 4); I. Iliev, Teofilakt Ochridski, w: Kirilo-Metodievska Enciklopedija, IV, Sofia 2003, 53.

${ }^{2}$ Por. Obolenski, Šest vizantijskich portretov, s. 428.

${ }^{3}$ Szerzej na temat szkoły patriarchatu konstantynopolitańskiego por. R. Browning, The Patriarchal School of Constantinople in the Twelfth Century, „Byzantion” 32 (1962) 167-202; 33 (1963) 11-40.

${ }^{4}$ Por. Obolenski, Šest vizantijskich portretov, s. 428-429.

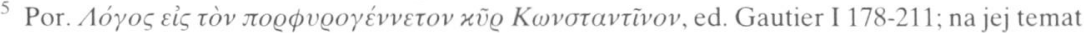
B. Leib, La Basilike Paideia de Théophylacte, archévêque de Bulgarie, et sa contribution à l'histoire de la fin du XI siècle, REB 11 (1953) 197-204; Gautier I 48-67. 
syn cesarza. Do tej decyzji pozytywnie ustosunkował się sam Teofilakt w mowie poświęconej Aleksemu Komnenowi, a wygłoszonej najprawdopodobniej 6 stycznia 1088 roku $^{6}$. Fakt ten jest ostatnim znanym nam wydarzeniem z życia Teofilakta sprzed jego pobytu w Ochrydzie. Nie ma jasności, co zadecydowało o wyniesieniu dotychczasowego diakona i wybitnego retora do tejże godności ${ }^{7}$. Nie ma to jednak specjalnego znaczenia dla podjętej przeze mnie kwestii, którą stanowi sposób postrzegania przez niego Konstantynopola, stolicy Imperium Bizantyńskiego ${ }^{8}$. Podstawę źródłową rozważań stanowią listy Teofilakta, pochodzące z czasów, kiedy sprawował godność ochrydzkiego pasterza ${ }^{9}$. Jednym z wątków, jaki się w nich pojawia, są odniesienia do stołecznego miasta.

Teofilakt był mocno związany z Konstantynopolem. Spędził w nim, jak się sądzi, ok. 20. lat życia i powracał do niego przynajmniej dwukrotnie w czasie swojego urzędowania w Ochrydzie ${ }^{10}$. Na pobyt w Konstantynopolu przypadła młodość Teofilakta, w nim rozpoczął swoją karierę naukową i pedagogiczną, i szybko zyskał uznanie, ciesząc się sławą znakomitego teologa, nauczyciela i mówcy. Był z pewnością wybitnym intelektualistą swoich czasów, ale i człowiekiem chyba trochę próżnym, który czerpał radość z tego, iż jest postacią znaną i podziwianą ${ }^{11}$. Był szanowany przez samego cesarza, który powierzył mu nauczanie następcy tronu. Wśród przyjaciół Teofilakta znajdowała się Maria z Alanii, ekscesarzowa, i szereg znaczących postaci z kręgów dwor-

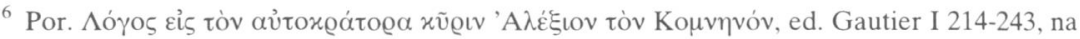
jej temat - tamże, s. 68-96; M. Tziatzi-Papagianni, Zur Panegyrischen Rede des Theophylactos von Achrida auf Kaiser Alexios I. Komnenos, JÖB 54 (2004) 191-206. Kwestia datacji wygłoszenia tej mowy nie jest rozstrzygnięta. Sytuuje się ją między styczniem 1088 a 1092 rokiem. Na ten temat zob. Testimonia 4 , s. 181 .

${ }^{7}$ Część uczonych uważa, że w ten sposób Teofilakt został ukarany za bliskie związki z rodziną Dukasów, dla innych była to nagroda za jego wybitne osiągnięcia, a i pewną elastyczność poparcie idei przekazania władzy Janowi, a nie Konstantynowi; są również i tacy, którzy sądzą, iż Teofilakt uznawany był za najlepiej przygotowanego do realizacji hellenizacji (romeizacji) Bułgarów. Poglądy dotyczące powodów wyniesienia Teofilakta do godności arcybiskupa Ochrydy przedstawiają: D. Obolenski (Šest vizantijskich portretov, s. 430), I. Iliev (Teofilakt Ochridski, archiepiskop blgarski, „Istorija” 5:1996, nr 1,29) i M. Angold (Church and Society in Byzantium under the Comneni 1081-1261, Cambridge 2000,160). Wydaje się, że rację mają ci uczeni, którzy dopatrują się w nominacji Teofilakta docenienia przez Aleksego jego osobowości, dotychczasowych dokonań, jak i sporej dozy zaufania, którą go obdarzał. O polityce Aleksego I wobec Kościoła por. J.M. Hussey, The Orthodox Church in the Byzantine Empire, Oxford 1986, 142nn; Angold, Church and Society, s. 45-72.

${ }^{8}$ Na temat ukazywania Konstantynopola w literaturze bizantyńskiej por. L. Simeonova, Konstantinopol prez pogleda na svoite ziteli ot elita i prostoljudieto (vtorata polovina na IX - načaloto na XI vek), ,Istoričeski Pregled” 56 (2000) z. 3-4, 16-29 (tam dalsza literatura przedmiotu).

9 Por. Théophylacte d'Achrida, Lettres. Introduction, texte, traduction et notes P. Gautier, Thessalonique 1986. Nie wiadomo jak długo przebywał Teofilakt w Ochrydzie. Uczeni datują kres jego pobytu w tej miejscowości między 1108 a 1126 rokiem.

${ }^{10}$ Por. Obolenski, Šest vizantijskich portretov, s. 437; Mullet, Theophylact of Ochrid, s. 262.

11 Por. Epistula 44, thum. Testimonia 4, s. 214: „[...] my przez wielu ludzi cenieni i podziwiani”. 
skich $^{12}$. Rozmiłowany w księgach i nauce w stołecznym mieście przyszły arcybiskup znalazł nie tylko optymalne warunki do prowadzenia naukowej działalności, ale i dla zdyskontowania swoich osiągnięć poprzez zyskanie autorytetu i prestiżu. Żadne inne miasto w Imperium nie mogło dać ambitnemu uczonemu takich możliwości. Teofilakt doskonale zdawał sobie z tego sprawę i doceniał to, że mógł być Konstantynopolitańczykiem ${ }^{13}$. W takiej sytuacji decyzja cesarza Aleksego I Komnena o mianowaniu go arcybiskupem Ochrydy, czego konsekwencją było opuszczenie Konstantynopola, choć z pewnością była wyrazem uznania dla jego dotychczasowych osiągnięć, nie została przyjęta przez niego z radością. Został przecież zmuszony do opuszczenia znanego i kochanego przez siebie świata, przeto nie musi specjalnie dziwić, że traktował swoją misję na ziemiach bułgarskich, jako zesłanie ${ }^{14}$.

Dla rozważanej przeze mnie kwestii ważne jest i to, że Teofilakt dobrze znał warunki życia w Konstantynopolu i obeznany był z funkcjonowaniem cesarskiego dworu. Jako opiekun Konstantyna Dukasa był pałacowym bywalcem. Orientował się zapewne w mechanizmach działania administracji cesarskiej i roli, jaką odgrywał w niej sam cesarz. Doświadczenia, jakie zebrał w kontaktach z dworem stały się podstawą do opinii, które w swoich listach wypowiadał na temat cesarza i jego urzędników. Uwagi te pojawiają się w kontekście konkretnych spraw dotyczących arcybiskupstwa ochrydzkiego, jak i kwestii bezpośrednio dotykających jego samego.

W korespondencji Teofilakta nie ma opisów Konstantynopola: nie było takiej potrzeby. Adresatami listów, w których znajdujemy odniesienia do Miasta, byli bowiem najczęściej jego mieszkańcy, lub ludzie którzy spędzili w nim sporo czasu i dobrze go znali. W listach tych pojawiają się natomiast refleksje dotyczące Miasta. Związane one są z kilkoma kwestiami, a mianowicie: stołecznego miasta jako ośrodka nauki, jako centrum politycznego i wreszcie jako miejsca, gdzie można podreperować zdrowie. Ze względu na ograniczoność miejsca przedstawione ponizej uwagi stanowią jedynie wprowadzenie do podjętego tematu, który z pewnością wymaga dalszych studiów.

${ }^{12}$ Na temat powiązań Teofilakta por. S.I. Maslev, Proizvedenija na Teofilakt Ochridski, archiepiskop blgarski otnacjašči se do blgarskata istorija, I: Proučvanija vrchu njakoj proizvedenija na Teofilakt Ochridski, archepiskop blgarski (1090-okoto 1126), Sofia 1974, 16-87; Gautier, Introduction, w: Théophylacte d'Achrida, Lettres, s. 37-131; Mullet, Theophylact of Ochrid, s. $293 \mathrm{nn}$.

${ }^{13}$ Por. Epistula 4, Testimonia 4, s. 186 (w liście tym z dumą określa siebie ,,bezwarunkowym

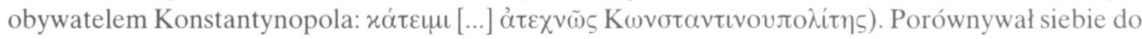
nieszczęśliwie zakochanego, który tęskni za ukochaną, tak jak on za swoim miastem. Sądzę, że tęsknota Teofilakta była autentyczna i nie może być uznawana za wyraz mody, która istniała w kręgach ówczesnej elity, której przyszło przebywać poza stołecznym miastem, zob. Obolenski, Šest vizantijskich portretov, s. 437; M.J. Leszka, Teofilakt, arcybiskup Ochrydy - bizantyński pasterz bułgarskiej „trzody”, „Balcanica Posnaniensia” 14 (2007) [w druku] - tam dalsza literatura przedmiotu.

${ }^{14} \mathrm{Na}$ temat stosunku Teofilakta do swego pobytu w Ochrydzie por. M.J. Leszka, j.w.. 
1. Konstantynopol jako centrum naukowe. Tym, co najboleśniej odczuwał arcybiskup w Ochrydzie, to brak dostępu do książek. Nie było to żadnym problemem w stołecznym mieście ${ }^{15}$. Utyskiwania ${ }^{16}$ Teofilakta w tym zakresie nie muszą specjalnie dziwić. Dla intelektualisty jego pokroju kontakt z książkami był elementarną potrzebą, którą przez 20 lat realizował w Kostantynopolu, z którym z pewnością Ochryda, pod względem zasobów książkowych, nie mogła konkurować. Stołeczne miasto jawi się, przeto jako najważniejsze centrum kulturalne i naukowe współczesnego Teofilaktowi świata. W jednym

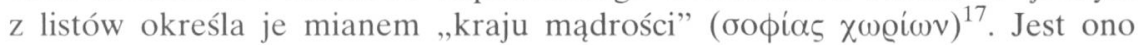
jedynym ośrodkiem, w którym można zdobyć prawdziwą sławę i uznanie. Teofilakt w liście do Taroneitopulosa, duksa Skopje nadmienia, że niektórzy spośród podległych mu biskupów zanim objęli swoje katedry „w Konstantynopolu zasłynęli mową i nauczaniem"18. Jak z tego wynika, osiągnięcie uznania w stolicy stanowi przepustkę do zajmowania ważnych godności kościelnych. Retor, nauczyciel, który sprawdził się w stolicy, zasługuje na urząd, a i daje gwarancję, że poradzi sobie z nowymi obowiązkami. Najlepszym potwierdzeniem tego poglądu, jak można by spointować, jest autor wspomnianego listu.

2. Konstantynopol jako centrum polityczne. Dla Teofilakta stołeczne miasto było politycznym centrum bizantyńskiej ekumeny ${ }^{19}$. Tu przebywał cesarz, tu pracowała rzesza urzędników mających wpływ nie tylko na życie Konstantynopolitańczyków, ale i każdego poddanego cesarskiej władzy. Czytając listy Teofilakta dostrzec można wyraźną różnicę w sposobie ukazywania cesarza i kadry urzędniczej. Dla arcybiskupa Ochrydy cesarz jest potężny (x@átı-

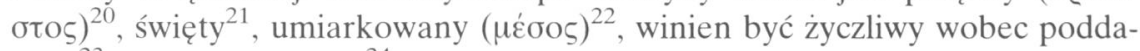
nych $^{23} \mathrm{i}$ im współczujący ${ }^{24}$. Przywołane cechy mieszczą się znakomicie w katalogu cech przypisywanych idealnemu władcy. Teofilakt używa wspomnianych określeń pod adresem konkretnego cesarza, którym w tym czasie był Aleksy

${ }^{15}$ Na temat środowiska naukowego Konstantynopola czasów Teofilakta por. Mullet, Theophylact of Ochrid, s. 48nn.

16 Por. np. Epistula 34

17 Por. tamże, Testimonia 4, s. 211

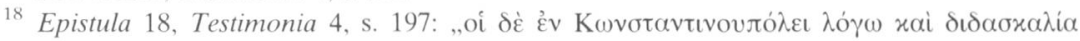
$\lambda \alpha \dot{\mu} \psi \alpha \alpha \tau \varepsilon \varsigma " ; ~ z o b . ~ M u l l e t$, Theophylact of Ochrid, s. 263.

${ }^{19}$ Na temat ukazywania przez bizantyńskich autorów tego aspektu funkcjonowania Konstantynopola por. Simeonova, Konstantinopol prez pogleda na svoite żiteli, s. 23-24.

20 Por. Epistulae 58; 85, 92, 98, Testimonia 4, s. 226, 246, 256.

21 Por. Epistula 58, Testimonia 4, s. 226.

22 Por. Epistula 55, Testimonia 4, s. 221

23 Por. Epistula 68, Testimonia 4, s. 235. Tak chyba można rozumieć fragment listu, w którym czytamy, ze Grzegorzowi Pakurianowi prawo do swobodnej wypowiedzi wobec cesarza daje jego (tj. Pakuriana?) życzliwość wobec poddanych. Cesarz musiał reprezentować więc taką samą postawę.

24 Por. Epistula 98, Testimonia 4, s. 260. 
I Komnen, a do którego on sam skierował, jak wspominałem, mowę, w której ukazał go właśnie jako idealnego władcę. Ale obraz basileusa w listach Teofilakta nie jest całkowicie jednobarwny. Oto bowiem wyraźnie wynika z nich, że cesarz nie jest nieomylny, że daje czasami wiarę fałszywym oskarżeniom, czego sam arcybiskup doświadczy ${ }^{25}$. Widać tu zawoalowaną nutę krytyki pod adresem Aleksego Komnena, który, zdaniem Teofilakta, nie wsparł go stanowczo w obliczu niesłusznych oskarżeń. Natomiast zdecydowanie już negatywną ocenę daje Teofilakt konstantynopolitańskim urzędnikom i tym, którzy z Konstantynopola zostali wysłani na ziemie ochrydzkiego arcybiskupstwa. Stołeczne miasto jawi się jako świat, w którym rządzi oszczerstwo, fałszywe oskarżenia, gdzie niełatwo jest znaleźć sprawiedliwość, gdzie rodzą się spiski. Ludzie przybywający do Miasta imają się wszelakich metod chcąc osiągać swoje cele, co uderza w uczciwych ludzi, a do takich z pewnością zalicza siebie arcybiskup Ochrydy.

W liście do Adriana, brata Aleksego Komnena, Teofilakt tak przedstawił sposób rozwiązywania swojej sprawy:

„Gdy wczoraj i przedwczoraj wystąpili przeciwko mnie fałszywi świadkowie, potężny nasz cesarz i twój umiłowany brat po ujawnieniu kłamstwa spowodował, że nie powiódł się ich spisek, i mimo że niesprawiedliwość sama w sobie została udaremniona, oni znowu do niego przybyli i to samo przedstawiali w tej samej sprawie. Do tego stopnia zdołali [wpłynąć na cesarza], że owe białe kamyki oddane na rzecz naszej racji teraz wpadły w otchłań i zamieniono je na czarne, co wywołało przygnębienie, a sąd $\mathrm{w}$ istocie cesarski stał się podobny do tkaniny Penelopy za dnia tkanej prawdziwie, noc zaś prutej dla wywołania fałszywego wniosku [...]"26

Teofilakt twierdzi, że przysyłani z Konstantynopola urzędnicy, których nazywa achridiotami, traktują mieszkańców prowincji z wyższością, można by rzec, że są wobec nich aroganccy. Nie można stawić im oporu, bo: „Któż bowiem przeciwstawi się obywatelowi Konstantynopola"27. Teofilakt-Konstantynopolitańczyk reprezentuje tutaj, sposób widzenia Miasta z perspektywy mieszkańca prowincji ${ }^{28}$.

Konstantynopol jako centrum polityczne państwa bizantyńskiego w listach Teofilakta wyraźnie odmalowany jest w ciemnych barwach, a co znamienne, krytyce arcybiskupa podlegają nie tylko kręgi urzędnicze, metody rozwiązywania spraw poddanych, ale i w pewnym, choć zdecydowanie skromniejszym stopniu, także sam cesarz. Pointując tę część moich rozważań można stwierdzić, że Teofilakt z pewnością za ,politycznym” Konstantynopolem nie tęsknił.

25 Por. Epistulae 85 i 96, Testimonia 4, s. 246 i 252.

${ }^{26}$ Epistula 85, Testimonia 4, s. 246.

27 Epistula 57, Testimonia 4, s. 223.

28 Na temat ukazywania Konstantynopola z perspektywy prowincji por. I. Ševčenko, Constantinople viewed from the Eastern Provinces in the Middle Byzantine Period, ,.Harvard Ukrainian Studies" 3-4 (1979-1980) 712-741. 
3. Konstantynopol jako miejsce ratowania zdrowia. Teofilakt $w$ swoich listach podnosił stosunkowo często kwestie związane $\mathrm{z}$ medycyną ${ }^{29} \mathrm{i}$ stanem swojego zdrowia. Jego narzekanie na różnego rodzaju przypadłości zdrowotne, których miał doświadczać, stało się podstawą do określenia go przez Dymitra Obolenskiego wręcz mianem hipochondryka ${ }^{30}$. Z perspektywy analizowanego przeze mnie tematu nie ma znaczenia, na ile przypadłości zdrowotne były wymysłem mojego bohatera, na ile zaś dotykały go w rzeczywistości. Natomiast istotne jest to, iż uważał, że skutecznie można leczyć się w Konstantynopolu $^{31}$. Choć Teofilakt nie podaje argumentów, które uzasadniałyby ten pogląd, to wskazanie ich, jak sądzę, nie jest kwestią skomplikowaną. List 113, w którym pada stwierdzenie o tym, że Teofilakt chciałby leczyć się w Konstantynopolu, dostarcza nam wskazówki, iż arcybiskup sądził, że klimat Konstantynopola zdecydowanie przyjaźniejszy jest dla ludzi, w tym, co oczywiste, dla chorych, niż choćby klimat Ochrydy. Co prawda pogląd ten expresis verbis nie został wyrażony, ale w kontekście narzekań na klimat Ochrydy jest on uzasadniony, szczególnie jeśli ma się w pamięci pochwałę konstantynopolitańskiego klimatu, którą Teofilakt zawarł w mowie $O$ wyksztatceniu cesarza ${ }^{32}$. Łagodny zimą i latem klimat stołecznego miasta sprzyjać zapewne musiał wszelakim kuracjom.

Drugim, najistotniejszym powodem, dla którego było ono doskonałym miejscem, w którym powinno się poddawać leczeniu, to kadra lekarska ${ }^{33}$. Najlepsi ówcześni lekarze znajdowali się na dworze cesarskim, a i poza nim w Konstantynopolu nie brakowało uznanych medycznych autorytetów. Takiego poglądu w listach Teofilakta nie znajdziemy, ale o poprawności tego wniosku świadczy fakt, że niejednokrotnie w swoich listach zwracał się do lekarzy konstantynopolitańskich ${ }^{34}$, prosząc ich o poradę, dotyczącą własnego zdrowia czy zdrowia Demetriusza, swego brata. Można by rzec, że zwracał się do nich, ponieważ znał ich z czasów, kiedy mieszkał w Konstantynopolu, ale nie jest dziełem przypadku, że wszyscy z nich byli cesarskimi lekarzami, a to był prze-

29 Szerzej na temat zainteresowań Teofilakta medycyną por. A. Leroy-Molinghen, Médecins, malades et remèdes dans Lettres de Théophylacte de Bulgarie, „Byzantion” 55 (1985) 483-492.

${ }^{30}$ Por. Obolenski Šest vizantijskich portretov, s. 441.

31 Por. Epistula 113, Testimonia 4, s. 264.

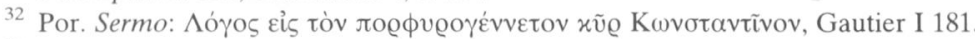

${ }^{33} \mathrm{Na}$ temat ukazywania lekarzy w bizantyńskiej literaturze czasów Teofilakta por. A. Kazhdan, The Image of the Medical Doctor in Byzantine Literature of the Tenth to the Twelfth Centuries, DOP 38 (1984) 44-51.

${ }^{34}$ Adresatem jego listów jest Michał Pantechnes, były uczeń Teofilakta, lekarz Aleksego Komnena (Kazhdan, The Image of the Medical Doctor, s. 44; Obolenski, Šest vizantijskich portretov, s. 441; Mullet, Theophylact of Ochrid, s. 351; tu wyliczenie listów skierowanych przez Teofilakta i ogólna charakterystyka ich treści), Nicholas Kallikles, główny lekarz Aleksego Komnena (Obolenski, Šest vizantijskich portretov, s. 441-442; Mullet, Theophylact of Ochrid, s. 349) i Niketas, określony mianem cesarskiego lekarza (Mullet, Theophylact of Ochrid, s. 337 i 358). 
cież szczyt lekarskiej kariery. Pomijając ten fakt to musieli się oni cieszyć szacunkiem i uznaniem Teofilakta, bo zapewne nie zwracałby się do nich w istotnych dla siebie sprawach, a szukałby pomocy u kogoś innego, szczególnie, że dobrze orientował się w kwestiach medycznych ${ }^{35}$.

Kończąc niniejsze rozważania trzeba stwierdzić, iż dla Teofilakta Konstantynopol był miejscem szczególnym, które ukochał, a z którego rozkazem cesarskim został wysłany do Ochrydy. Będąc tamtejszym arcybiskupem Teofilakt tęsknił za Miastem i prągnął powrotu do niego. Konstantynopol, o którym marzył, to miejsce, gdzie można pracować naukowo i cieszyć się zasłużoną sławą, a także właściwie dbać o zdrowie korzystając z przyjaznego ludziom klimatu i płodów okalających go terenów. Teofilakt nie podchodził jednak do Konstantynopola bezkrytycznie - dostrzegał złe strony funkcjonowania Miasta - świat polityki, intryg, zabiegów najpodlejszymi sposobami o cesarską łaskę. Takiego Konstantynopola nie akceptował i w ostrych słowach krytykował.

\title{
CONSTANTINOPLE IN THE LETTERS BY THEOPHYLAKT, THE ARCHBISHOP OF OCHRID
}

\author{
(Summary)
}

The article discusses the manner adopted by Theophylakt, the archbishop of Ochrid, an eminent theologian, rhetor and teacher living at the end of the $\mathrm{XI}^{\text {th }}$ and the beginning of the XII ${ }^{\text {th }}$ centuries, to describe Constantinople, the capital of the Byzantine Empire.

In the letters written during the period of his waging arch-episcopal power (to which he was promoted by emperor Alexios I Komnenos) his thoughts would fairly regularly come back to the capital city. Constantinople was for him a very special place, which he loved, missed and to which he longed to return to. The metropolis he dreamt of was the place, where he could do his research, enjoy his well deserved fame, and also take care of his personal health by profiting from a friendly and healing climate and crops yielded by the region around.

However, his attitude towards the life of the capital city was also imbued with criticism. He was able to notice shady aspects of the city life, i.e. unacceptable realities of various political activities, intrigues and dishonest ways to win imperial favors. Such the Constantinople he disapproved of and severely criticized. 